Correa-Ochoa, M. A., Vélez-Monsalve, L. C., \& SaldarriagaMolina, J. C. (2021). Spatial distribution of lichen communities and air pollution mapping in a tropical city: Medellín, Colombia. Revista de Biología Tropical, 69(3), 1107-1123. https://doi.org/10.15517/rbt.v69i3.46934

\title{
Spatial distribution of lichen communities and air pollution mapping in a tropical city: Medellín, Colombia
}

\author{
Mauricio Andres Correa-Ochoa ${ }^{1 *}$; (D) https://orcid.org/0000-0003-3666-0767 \\ Leidy Catalina Vélez-Monsalve ${ }^{1}$; (D) https://orcid.org/0000-0003-2349-1044 \\ Julio César Saldarriaga-Molina ${ }^{1}$; (D https://orcid.org/0000-0002-9395-5417
}

1. Grupo de Investigación y Laboratorio de Monitoreo Ambiental-GLIMA, Grupo de Ingeniería y Gestión AmbientalGIGA, Escuela de Ingeniería, Universidad de Antioquia, Medellín, Colombia; mandres.correa@udea.edu.co (Correspondence*), lcatalina.velez@udea.edu.co,julio.saldarriaga@udea.edu.co

Received 10-V-2021. Corrected 12-VII-2021. Accepted 29-IX-2021.

\begin{abstract}
Introduction: Enough scientific evidence is available on the harmful effects of air pollution on the health of human beings, fauna, flora, and ecosystems in general. The mechanical and electronical monitoring networks are the first option for the air quality diagnosis, but they do not allow a direct and precise assessment of the impacts in living organisms that may result from the exposure to air pollutants.

Objective: To evaluate the changes in the composition of corticulous lichen communities as a response to various stress factors in areas with different levels of air quality to diagnose the state of pollution or intervention in an area with a more complete option.

Methods: Air quality contrasts and changes in richness and coverage of corticulous lichens in response to different stress factors, such as land use and distance to roads, in three different biomonitoring areas, were evaluate using GIS, and the data are presented in an easy-to-understand grey scale coded isoline map.

Results: Indicators such as lichen coverage $(\mathrm{R}=-0.4)$ and richness $(\mathrm{R}=-0.7)$ are inverse correlated with $\mathrm{PM}_{2.5}$ concentrations in each area. A total of 110 lichen species were identified, being Phaeophyscia chloantha (Ach.) Moberg and Physcia poncinsii Hue the most frequent species (present in 38 and $33 \%$ of the 86 sampled phorophytes, respectively). The intra-area relationships of lichen richness exhibit significant relationships with regards to the land use and distance to roads (with correlations coefficients greater than 0.5) and the Simpson index was higher than 0.9 , in places with better conditions in terms of air quality and microenvironments, likewise the resistance factors calculated suggest that the most sensitive species can be found in environments with a lesser degree of disturbance.

Conclusion: These evaluations represent more criteria elements for the diagnosis of the environmental health in the biomonitoring areas.
\end{abstract}

Key words: biomonitoring; air quality; corticulous lichens; resistance factors; mapping lichens; lichens diversity.

Worldwide, air pollution represents one of the greatest concerns because of its proven adverse effects on people's health (WHO, 2016a). These have been evidenced by a significant number of epidemiological studies developed in recent decades in different parts of the world, which have established a close relationship between the levels of pollutants (gases and particles) concentration in the air and increased mortality as well as hospital 
admissions for respiratory and cardiovascular conditions, among others (Aguiar-Gil et al., 2020; Cakmak et al., 2018; Li et al., 2018; WHO, 2016b).

One of the mandatory strategies that environmental authorities responsible for ensuring good air quality in their jurisdiction must undertake is the implementation of monitoring networks for atmospheric pollutants (Green \& Sánchez, 2012). The data reported by the measurement stations are the input for the formulation of the Integrated Management Plans for Air Quality (planning, implementation, and evaluation (AMVA \& Clean Air Institute, 2017). These plans will help achieve acceptable and safe standards for the welfare of inhabitants and ecosystems in general. However, a high percentage of the monitoring networks use expensive technology equipment that require periodic repair, maintenance, services, and specialized calibration procedures. In addition to the high acquisition costs, the operation, transportation, and custody (security) may condition the implementation in areas with difficult access and limited resources, such as energy services and stable communication (INE, 2019).

On the other hand, the complexity in the comprehensive assessment of air quality through the use of these technologies represents a strong limitation, since they are limited to certain chemical compounds and measure pollutants in isolation (WHO, 2006), and they do not allow the establishment of an intrinsic relationship with the biological effect of air pollutants and their long-term consequences on organisms, their communities, and the ecosystem in general (Castro et al., 2014).

Bioindication has been a tool used as a methodological alternative to contribute to the solution of the complex situation that arises in the field of environmental assessment. Moreover, it enables the answering of the questions or uncertainties that stem from the information generated by the conventional monitoring systems on the real physiological and behavioral effects to which organisms are subjected, both in space and time (Augusto et al., 2013; Kienzl et al., 2003; Van Dijk et al., 2015). Therefore, the use of different groups of organisms as indicators has been consolidated as an adequate alternative to evaluate the effect that may be derived from the deterioration of air quality in a territory under study. Due to their anatomical, morphological, and physiological characteristics, the lichen has been used as a bioindicator with successful results. Moreover, as they are widespread worldwide, lichens allow the determination of the involvement degree when they are exposed to dangerous substances, as in the case air pollutants, allowing the classification of some species as sensitive and others as tolerant (Anze et al., 2007; Cleavitt et al., 2015; Käffer et al., 2011; Jovan, 2008).

Lichens are intimate and long-lasting symbioses of photosynthetic algae or cyanobacteria and heterotrophic fungi (Piercey-Normore \& DePriest, 2001). This symbiotic relationship is related to their tolerance and / or sensitivity, so they can be used as bioindicators (Llop et al., 2012). Since the techniques for the implementation of their use as bioindicators can be considered simple and low-cost maintenance, lichens have great strengths as an instrument for the diagnosis of air quality (Correa-Ochoa et al., 2020; Hawksworth et al., 2005; Salcedo et al., 2014). Furthermore, they define air quality levels with greater precision, establishing limits that are difficult to be detected by conventional systems and allowing the determination of the degree of impact on humans, given that they are exposed to the same complex mixture of air pollutants (Castro et al., 2014).

The excellent results that the different biomonitoring programs with lichens have produced have served as an argument to integrate them into environmental assessment strategies of national protocols in countries such as England, Germany, the United States and the Netherlands (Anze et al., 2007; Käffer et al., 2011; Monge-Nájera et al., 2002). In this regard, the evaluation of the spatial behavior patterns of these air quality bioindicators has allowed the establishment of associations between their diversity, such as their bioaccumulation capacity, their relationship with the 
state of contamination in some areas, as well as their relationship with some diseases (Cislaghi \& Nimis, 1997; Pollard et al., 2015; Ribeiro et al., 2016; Yatawara \& Dayananda, 2019).

The articulation of current systems for measuring air quality and the use of bioindicators, represents an alternative that allows a better knowledge of pollution, especially in cities like Medellín that register areas with significant air quality alterations and that have a robust monitoring network for the diagnosis of air quality but do not have qualitative tools to assess its impact on living beings. In this sense, this study aims to evaluate the changes in the composition of corticulous lichen communities as a response to various stress factors in areas with different levels of air quality. This was achieved through the quantification of lichen richness and coverage, mapmaking, and the determination of relationships among these parameters, land uses, and distance to roads in the different biomonitoring areas, located in Medellín city.

\section{MATERIALS AND METHODS}

Study site: Medellín city is located in the central mountain range of the Colombian Andes (Fig. 1A and Fig. 1B) at an average height of $1450 \mathrm{~m}$ above sea level; it is centered in a deep $(1 \mathrm{~km})$ and narrow $(10 \mathrm{~km}$ on average) valley called Valle de Aburrá. The city has a temperate-dry climate, with average
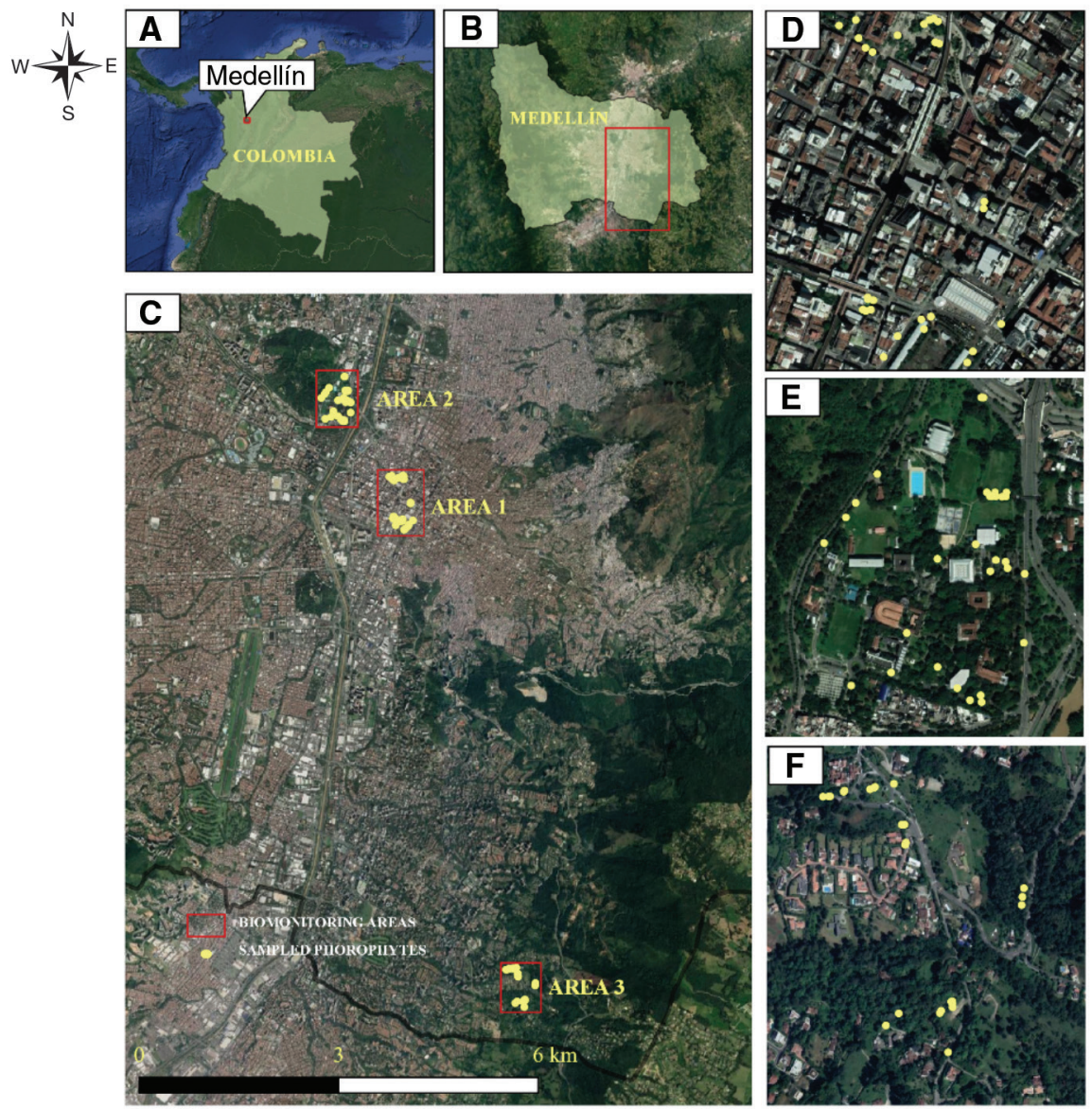

Fig. 1. Biomonitoring area. A. Study area location in Colombia, B. Study area location in the City of Medellín, C. Biomonitoring areas, D. Area 1, E. Area 2, F. Area 3. (Coordinate system - WGS_1984). 
annual temperature values of $22.5^{\circ} \mathrm{C}$, precipitation of $1685 \mathrm{~mm}$, relative humidity of $67 \%$ (IDEAM, 2018a), and a predominant direction of the winds from North to South in the axis of the valley (IDEAM, 2018b). During recent years, the levels of air pollution in the valley have generated great concern; especially the $\mathrm{PM}_{2.5}$ particulate material (Gaviria et al., 2011; MADS, 2012). This, in addition to the valley's topography and the local and regional meteorological conditions that vary throughout the year, favors episodes of atmospheric stability (mainly in March-April and October-November) that influence the pollutants dynamic dispersion (Correa et al., 2009). Considering the risk that air pollution has on people's health, Valle de Aburrá has one of the most robust and advanced air quality networks in the region (BID, 2016) that is integrated into the Sistema de Alerta Temprana del Valle de Aburrá (SIATA).

Biomonitoring areas: This study was conducted in three biomonitoring areas (Fig. 1C) that present differences in their sources of air pollutant emission as well as physical and environmental conditions. Area 1 is located in the center of the city in a commercial and institutional sector, comprises emissions mainly due to vehicular traffic with roads where urban, inter-municipal, and private and public transport converge in the city. It has little vegetation with isolated trees, located mainly on platforms that are part of the urban planning of the area (Fig. 1D). On the other hand, Area 2 is characterized by heterogeneous conditions, combining exposure to high vehicular traffic and large vegetation areas (Fig. 1E). This area is located inside the Universidad Nacional de Colombia, which has a great number and diversity of tree species. Finally, Area 3 is located in an area with different characteristics from the previous ones (Fig. 1F). It is defined by predominant vegetation and scarce emissions of pollutants of industrial origin. This is an area of important contrast with land uses mainly forestry.
General air quality of the biomonitoring areas: The annual average concentrations of $\mathrm{PM}_{2.5}$ reported by SIATA for the year 2018 were inserted using Spline, a tool of ESRI's ArcGis ${ }^{\circledR}$ software to assign the air quality associated with the biomonitoring areas to generate isoconcentration maps of this pollutant. Subsequently, an estimated average value was obtained for this pollutant in each of the areas from the maps obtained and using the spatial analyst tools (Extract values to points) of ESRI's ArcGis ${ }^{\circledR}$ software.

Lichen species mapping, collection, identification and area determination: In each of the three biomonitoring areas, 28 to 30 phorophytes were sampled (without species differentiation). The field work focused on the identification of the number of lichen species and on the mapping of the specific coverage of lichens. Moreover, it followed the methodology proposed by Monge-Nájera et al. (2002), in which a transparent film of polyethylene terephthalate (acetate) of $50 \mathrm{~cm} \times 100 \mathrm{~cm}$ and 0.4 $\mathrm{mm}$ thickness was fixed on the bark of the tree at a height of $50 \mathrm{~cm}$, measured from the ground level up to the lower edge of the acetate on the side where the greatest presence of lichens was evident (Fig. 2A).

Subsequently, the outer contour of the lichen spot (no matter how type of thallus they have) was outlined with a fine-tipped marker using a different color for each lichen species (Fig. 2B). Each acetate was digitized at a 1:1 scale in the presence of a metric pattern and was stored in digital ".tiff" format. Then, each digitized image was processed using ARLIQ ${ }^{\circledR}$ software that determines the inventory of lichen cover (Fig. 2C and Fig. 2D) and the number of lichen species (lichen richness per phorophyte). The design of this software emerged as a tool to conduct a research project by GIGA and GEPAR groups of the Facultad de Ingenieria de la Universidad de Antioquia (UdeA).

Representative specimens were collected according to the methodology proposed by 
A

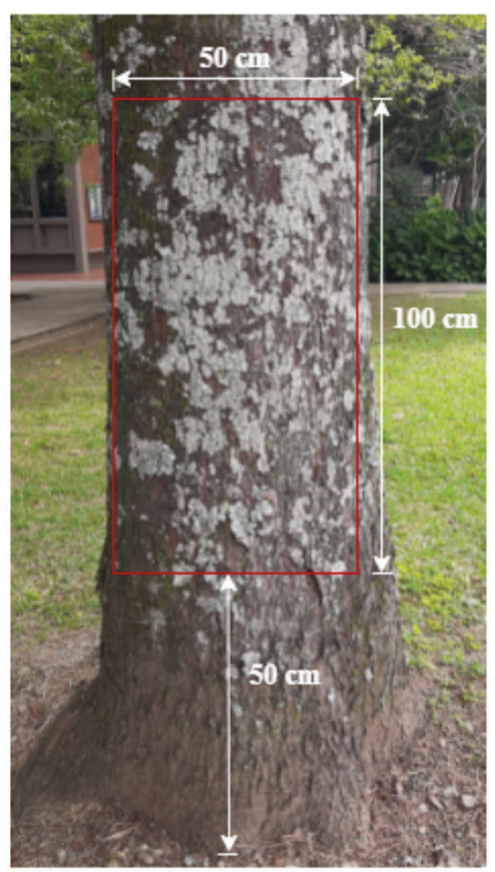

B

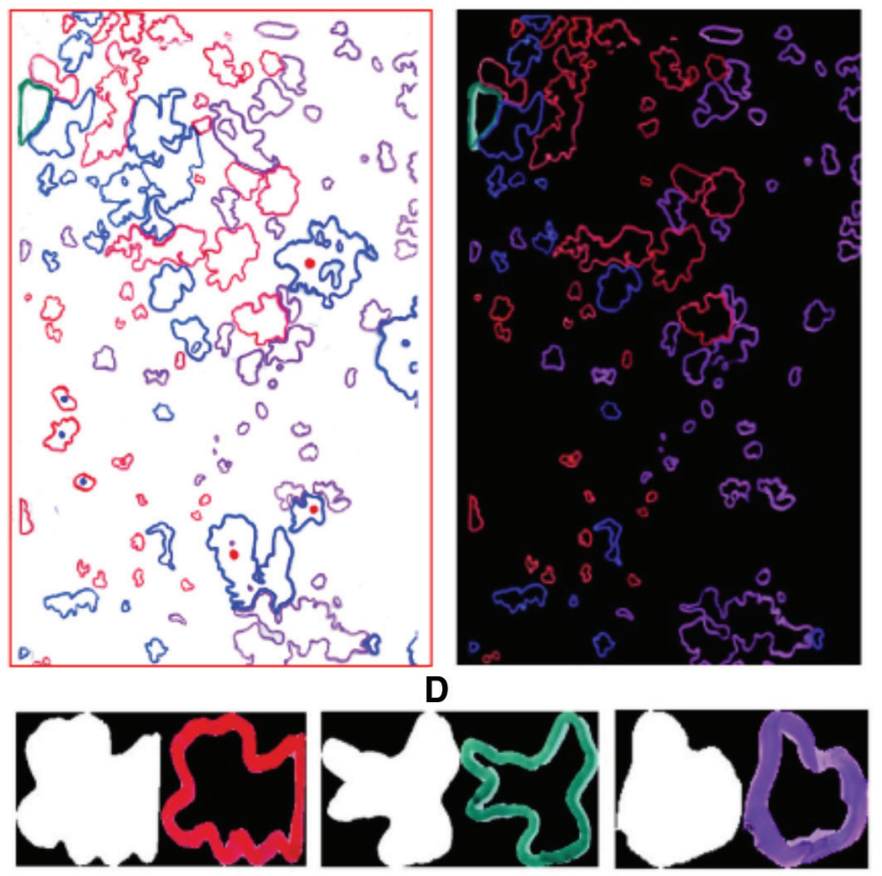

Fig. 2. Lichen mapping in phorophytes, and counting and inventory of lichen areas A. Acetate location in each phorophyte B. Acetate digitized with a metric scale C. Color identification. D. Quantification of the area.

Chaparro \& Aguirre (2002) and then the characterization of the lichen species was performed using the methodology of Orange et al. (2001).

\section{Simpson Index and resistance factor:} The Simpson Index (Simpson, 1949) was calculated for different intervals of distances (0-50 $\mathrm{m}, 50-100 \mathrm{~m}, 100-150 \mathrm{~m},>150 \mathrm{~m})$ in each area, with respect to the roads (Area 1 and 2) or respect to the forest area (Area 3). Likewise, the resistance factor, were calculated for the same distance intervals. This factor establishes the degree of sensitivity of the species, assuming that contamination reduces its diversity and the sensitivity of a specie depends on its representativeness in the environment in which it is found (Jaramillo \& Botero, 2010).

Data analysis: Kruskal-Wallis test were used to evaluate whether statistically significant differences were present between the richness and coverage medians of the mapped phorophytes in the biomonitoring areas and Mann-Whitney U were used to do paired comparisons between richness and coverage medias for different levels of these factors. Furthermore, the Moran index was also used to determine the possible existence of spatial clustering patterns of richness and coverage values.

The richness and lichen coverage values obtained for each sampling unit were interpolated using two mathematical algorithms: Inverse Distance Weight (IDW) and Radial Basis Function (Spline). Geostatistical Analyst ${ }^{\circledR}$ tool of ESRI's ArcGis ${ }^{\circledR}$ software was used to perform all the analyses. The algorithm with the best performance was chosen to represent the distribution of lichens.

The performance of each interpolation algorithms was performed using the leave one out cross validation method (James et al., 2013), and then calculating the index 
of agreement (IOA), root mean square error (RMSE), and the RMSE standardized (RMSS). The best mathematical performance algorithm comprised the lowest RMSE and an RMSS and IOA closer to 1 (Chai \& Oceanic, 2015; Szpiro et al., 2007; Willmott et al., 2012).

The relationships between intra-area lichen richness and cover, land use, and roads distances were evaluated using the Spearman correlation coefficient. The information regarding the road network and land use was downloaded from the official public website GeoMedellín (Alcaldía de Medellín, 2021). The phorophytes distances to the roads and soil types were calculated using the Euclidean Distance tool of ArcGis ${ }^{\circledR}$ Software; the number of lichen species was calculated for different intervals of distances (0-50 m, 50-100 m, 100-150 m, >150 $\mathrm{m}$ ) in each area, with respect to the roads (Area 1 and 2) or respect to the forest area (Area 3). Likewise, the Simpson index (Simpson, 1949) were calculated for the same interval distances and the resistance factor of each lichen specie (Correa-ochoa et al., 2020) were calculated for the same distance intervals. Finally, a KruskalWallis test was used to determine the existence of statistically significant differences in the resistance factor between distance intervals, and the Mann-Whitney $U$ were used to do paired comparisons between the resistance factor medias in the different distance intervals. All analyses were carried out using software RStudio version 3.6.3 (RStudio Team, 2020).

\section{RESULTS}

Air quality in biomonitoring areas: Fig. 3A shows the air pollution patterns associated with the annual average of $\mathrm{PM}_{2.5}$ for the study area in 2018. The highest estimated concentration is in Area 1 with $26.93 \mu \mathrm{g} / \mathrm{m}^{3}$, followed by Area 2 with $21.29 \mu \mathrm{g} / \mathrm{m}^{3}$, and finally, Area 3 with $18.84 \mu \mathrm{g} / \mathrm{m}^{3}$ (Fig. 3B).

Lichen diversity, coverage, and richness in the biomonitoring areas: 110 species of lichens were identified. The most frequent was Phaeophyscia chloantha (Ach.) Moberg, that was present in 33 of the 86 phorophytes evaluated in all areas, followed by the Physcia poncinsii Hue that was in 28 phorophytes. The highest number of species was in Area 1 with 84, followed by Area 2 with 44, and finally, Area 3 with 23. In Area 1, Phaeophyscia chloantha (Ach.) Moberg (21 of the 30 phorophytes) and Candelaria concolor (Dicks.) Arnold (20 of the 30 phorophytes) were dominant and for Area 3, Candelaria fibrosa (Fr.) Müll. Arg (12 of the 26 phorophytes) was dominant.
A

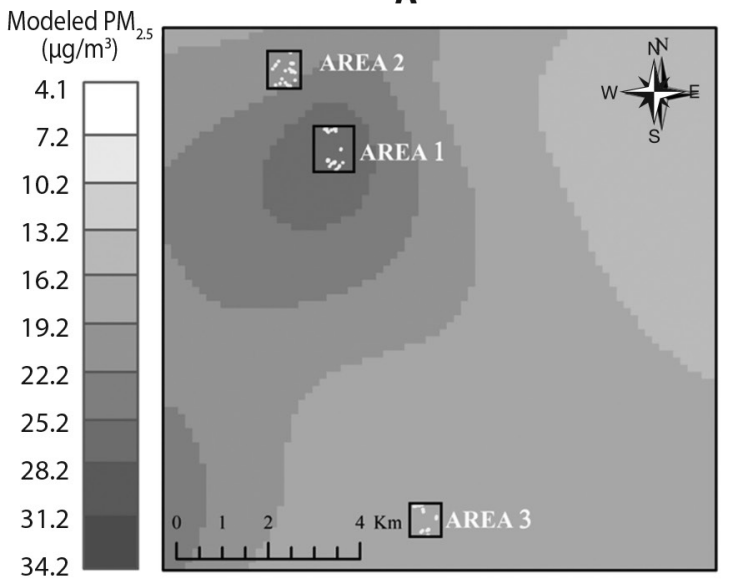

B

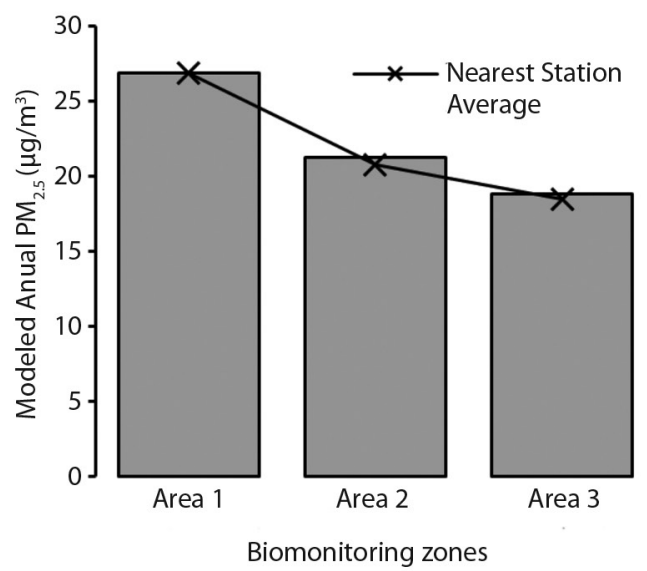

Fig. 3. A. Modeled Annual Concentration of $\mathrm{PM}_{2.5}$ (general error of Spline interpolator with an error of $\pm 4.97 \mu \mathrm{g} / \mathrm{m}^{3}$ ) B. Modeled Annual Concentration in the biomonitoring areas. 

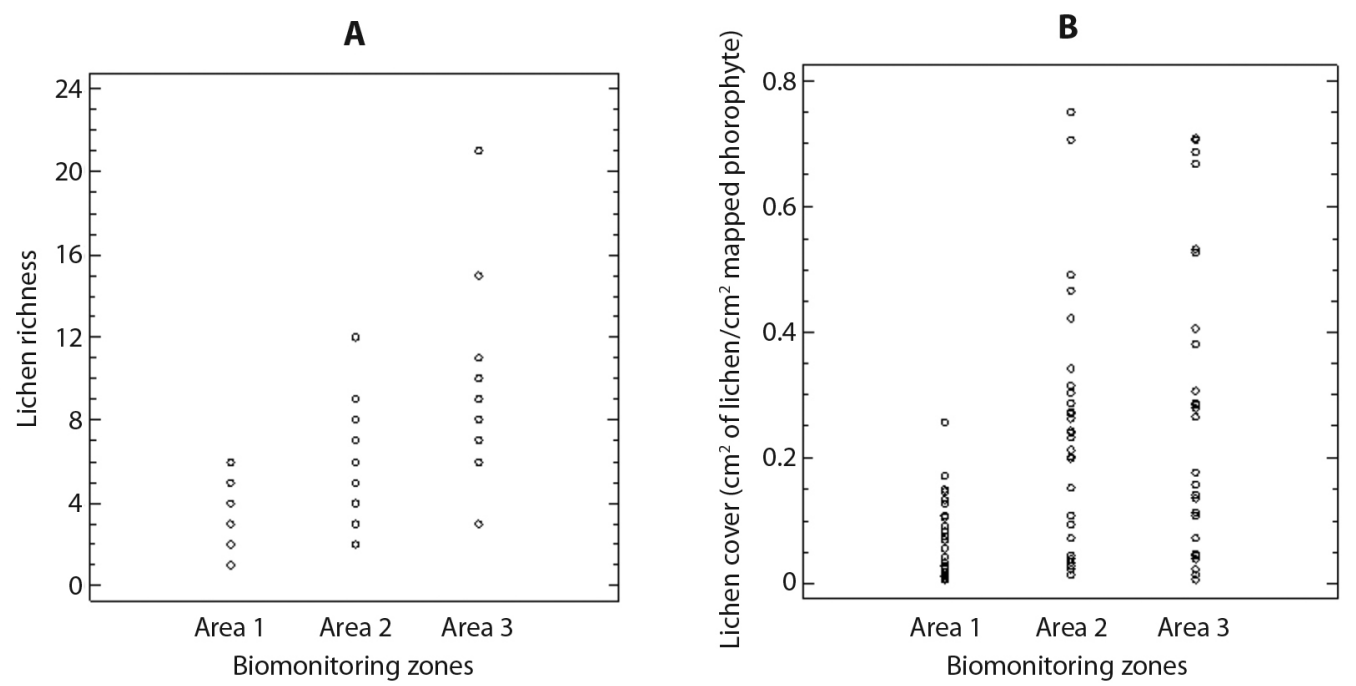

Fig. 4. A. Lichen richness B. Lichen cover.

According to the Kruskall-Wallis test, statistically significant differences were present in at least one of the richness $(\mathrm{P}<0.05)$ and coverage $(\mathrm{P}=0.00)$ medians in the biomonitoring areas, and the paired comparisons (MannWhitney $U$ test) for richness values in the biomonitoring areas, the test indicates statistically significant differences in the medians for all the pair comparisons evaluated. Also, $\mathrm{PM}_{2.5}$ values are negatively correlated with richness $(\mathrm{R}=-0.7)$ and coverage $(\mathrm{R}=-0.4)$ in the biomonitoring zones (Fig. 4A). Similarly, for coverage values in the biomonitoring areas indicated significant differences between areas $1-2$ and $1-3$ ( $\mathrm{P}<0.05$ in both cases $)$; while no statistically significant differences were found for this variable in areas $2-3(\mathrm{P}=0.88)$ (Fig. 4B).

Performance of spatial interpolation algorithms and spatial patterns of lichen richness and lichen coverage: The results of the Moran Index indicate that clustering patterns (With $\mathrm{z}$ values $>0$ ) are presented in the observations of richness $(\mathrm{z}=6.7, \mathrm{P}=0.00)$ and coverage $(\mathrm{z}=3.65, \mathrm{P}=0.00)$ and there is spatial autocorrelation of the observations with
$\mathrm{P}$-values $<0.05$, indicating that there is a probability of less than $1 \%$ that these clusters are the result of chance.

The Spline model was the chosen model, since, in the case of richness, it presented a lower RMSE and an RMSS and IOA closer to one in relation to the $I D W$ model. In the case of coverage, it presented an RMSS closer to one and a lower RMSE (Fig. 5A). The errors associated with the interpolation model of the richness and coverage values can be observed in Fig. 5B and Fig. 5C, where the error associated with the interpolation model is 2.3 for richness and $0.18 \mathrm{~cm}^{2}$ of lichen $/ \mathrm{cm}^{2}$ of mapped phorophyte for coverage.

Fig. 6 shows the land uses and pathways in each biomonitoring area (Fig. 6A, Fig. 6B and Fig. 6C). Spatial distribution patterns of the lichen richness (Fig. 6D, Fig. 6E and Fig. $6 \mathrm{~F}$ ) and coverage values (Fig. 6G, Fig. 6H and Fig. 6I) using the Spline spatial interpolation algorithm. According to the scales of the color patterns in the figure, it can be observed that the richness and coverage of lichens was lower in zone 1 compared to zones 2 and 3. Likewise, the zone that presented a higher value of richness and coverage was zone 3 . 
A

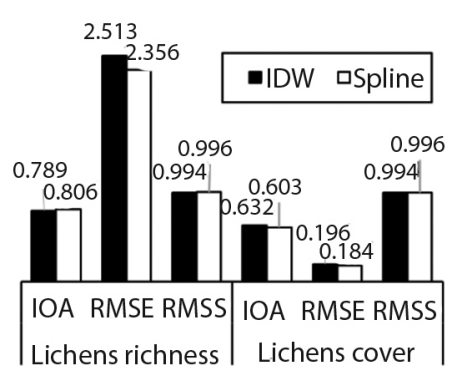

B

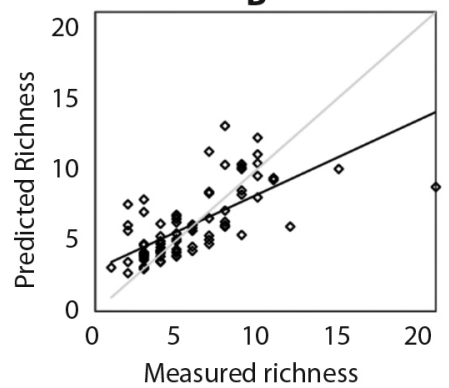

C

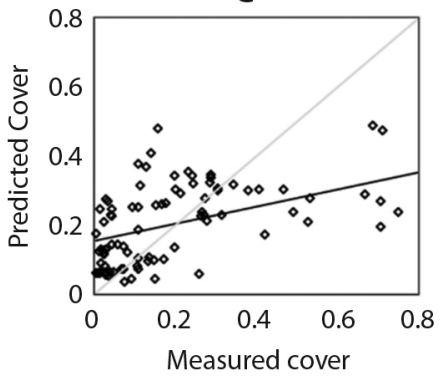

Fig. 5. A. Spatial interpolators comparison Spline and $I D W$ B. Predicted values adjustment vs. richness observed values C. Predicted values adjustment vs. observed values for coverage $\left(\mathrm{cm}^{2}\right.$ of lichen/ $\mathrm{cm}^{2}$ mapped phorophyte).

Lichen coverage and richness intra areas: A positive correlation was found between richness and distance to main roads (Fig. 7A) in Area $1(\mathrm{R}=0.58)$. In the case of coverage, no significant relationship was found with respect to the distance to main roads $(\mathrm{R}=$ $0.1338, \mathrm{P}=0.47$ ) in this area (Fig. 7B). In Area 2 we found a positively correlation $(\mathrm{R}=0.5)$ between lichen richness and distance to roads (Fig. 7C). In the case of coverage (Fig. 7D), no significant relationship was found with respect to the distance to roads at this site $(\mathrm{R}=0.04)$. Finally, in Area 3 richness values were negatively correlated $(R=-0.5)$ with the distance to the forest (Fig. 7E). For the case of the coverage (Fig. 7F), a moderate-low relationship was found $(\mathrm{R}=-0.39)$. Note: For Area 3 richness and cover values were correlated with distance to forest zona, given that the phorophytes sampled in this area were located on the sides of the roads (distance to roads $=0 \mathrm{~m}$ ) and not inside the forest area to avoid edge effects that could generate erroneous interpretations in the data analysis.

Species diversity estimators and resistance factor by distance intervals: Fig. 8 shows de number of species and the Simpson index for the areas in the different distance intervals to roads (Area 1 and 2) or to the forestry area (Area 3 ). The obtained results for area 1 (Fig. 8A) showed an increase in the number of lichen species as the distance intervals are further from the roads, presenting the highest number at distances $>150 \mathrm{~m}$ with a total of 18 lichen species. Likewise, the Simpson index was higher as the distance to the road increases. On the other hand, area 2 (Fig. 8B) presented the highest number of species in the distance to roads between 50 and $100 \mathrm{~m}$ with a total of 31 species; thereafter, the richness decreases when the distance to the roads increases, going from having 23 species between 100 and $150 \mathrm{~m}$ to 11 at distances $>150 \mathrm{~m}$. Regarding the Simpson index, its highest values were presented in the distance intervals between $50-100 \mathrm{~m}$ and between 100-150 m. Finally, in area 3 (Fig. $8 \mathrm{C}$ ), the highest number of species occurred in the distance interval between $0 \mathrm{~m}$ and $50 \mathrm{~m}$ from the forest zone with a total of 90 species and in that same distance interval the highest value of the Simpson index was presented.

According to the results of the KruskalWallis test there were statistically differences in the resistance factor for the different distance groups. For area 1 the resistance factors of the species located at distances $>150 \mathrm{~m}$ were higher (Fig. 9A) and the Mann-Whitney U test established that they were different from those reported for the other distance intervals. Likewise, this test established that there are no differences in the resistance factors of the species located in the distances between $0-50 \mathrm{~m}$, 50-100 $\mathrm{m}$ and 100-150 $\mathrm{m}$.

On the other hand, for area 2, there were statistically significant differences in the 

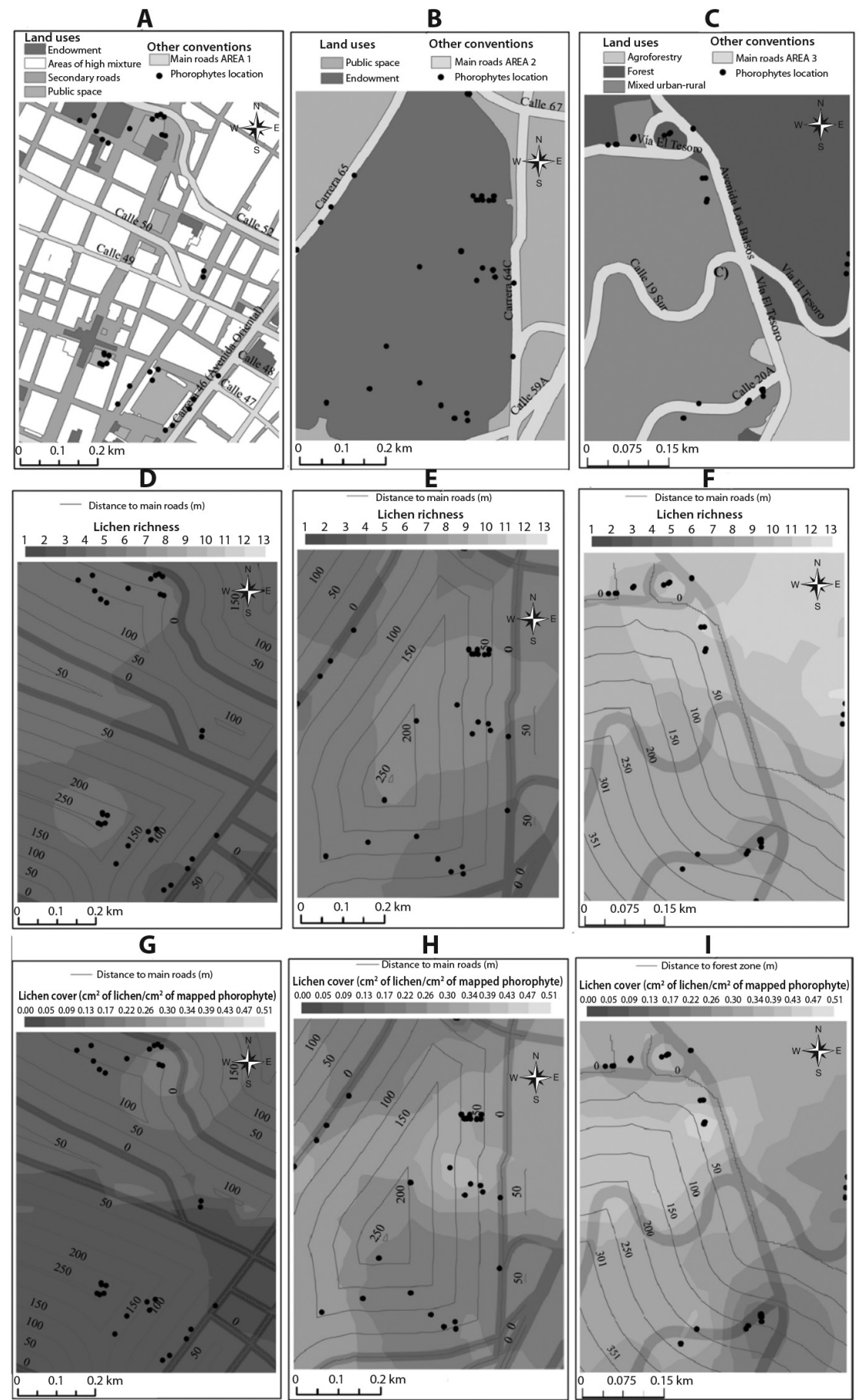

Fig. 6. Spatial distribution patterns of lichen cover and richness values using the Spline interpolation, and land uses and roads in each biomonitoring area. A. Area 1 land use and roads B. Area 2 land use and roads $\mathbf{C}$. Area 3 land use and roads D. Area 1 richness and main roads distances E. Area 2 richness and main roads distances $\mathbf{F}$. Area 3 richness and main roads distances G. Area 1 coverage and main roads distances H. Area 2 coverage and main roads distances I. Area 3 coverage and main roads distances. 
A

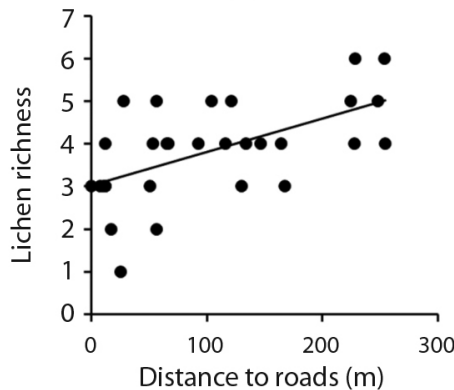

C

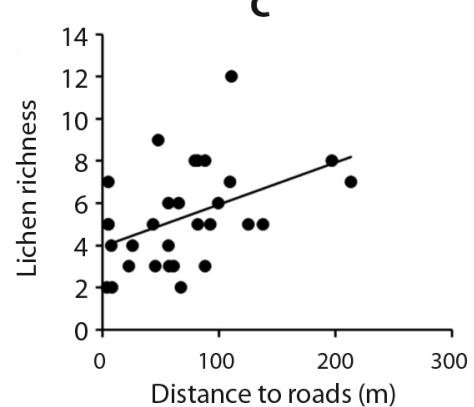

E

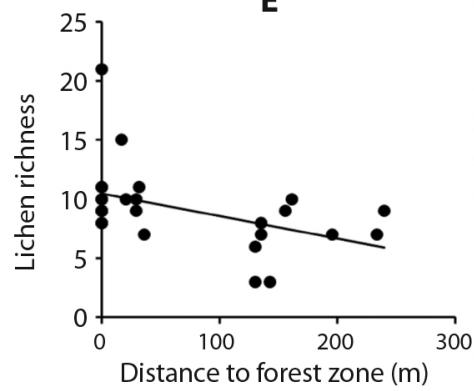

B

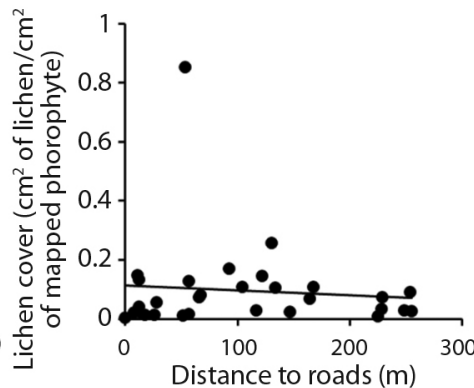

D

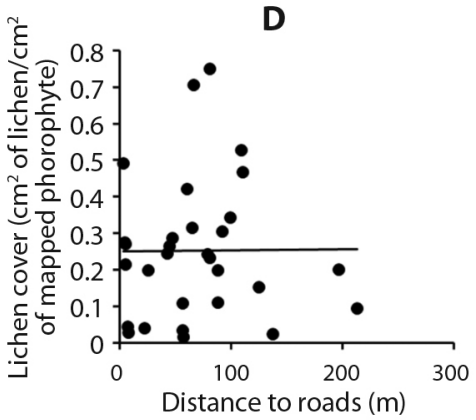

$\mathbf{F}$

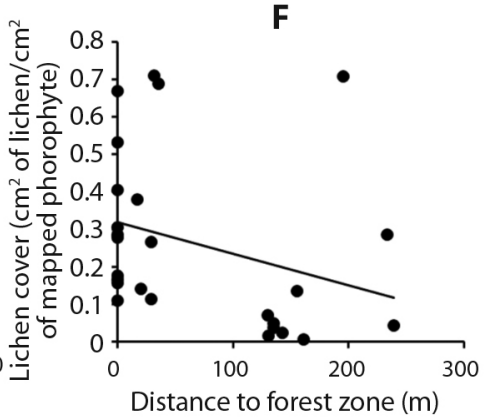

Fig. 7. Lichen richness and coverage in relation to the distance to roads or in relation to distance to forest region. A. Area 1 richness and main roads distances B. Area 1 cover and main roads distances $\mathbf{C}$. Area 2 richness and main roads distances $\mathbf{D}$. Area 2 cover and main roads distances E. Area 3 richness and forest zone distances $\mathbf{F}$. Area 3 cover and forest zone distances.

resistance factor for the different distance groups $(\mathrm{P}=0.000)$ and the Mann-Whitney $\mathrm{U}$ test identified two different homogeneous groups that establish that the resistance factor registered for the distance groups of 0-50 m, 50-100 $\mathrm{m}$ and 100-150 $\mathrm{m}$ does not present differences and that the resistance factor of the lichen species at distances $>150 \mathrm{~m}$ was different from that of the other distance groups. In this sense, for this distance interval it was found that the resistance factors were lower
(Fig. 9B). Finally, the resistance factor calculated for the lichen species in the different distance intervals for area 1 , present statistically significant differences $(\mathrm{P}=0.000)$, and three different homogeneous groups were identified according to the Mann-Whitney $U$ test. Therefore, the resistance factor is statistically different in the three distance ranges. In this sense, the resistance factor was higher for the species found closer to the forest zone $(0-50$ m) (Fig. 9C). 

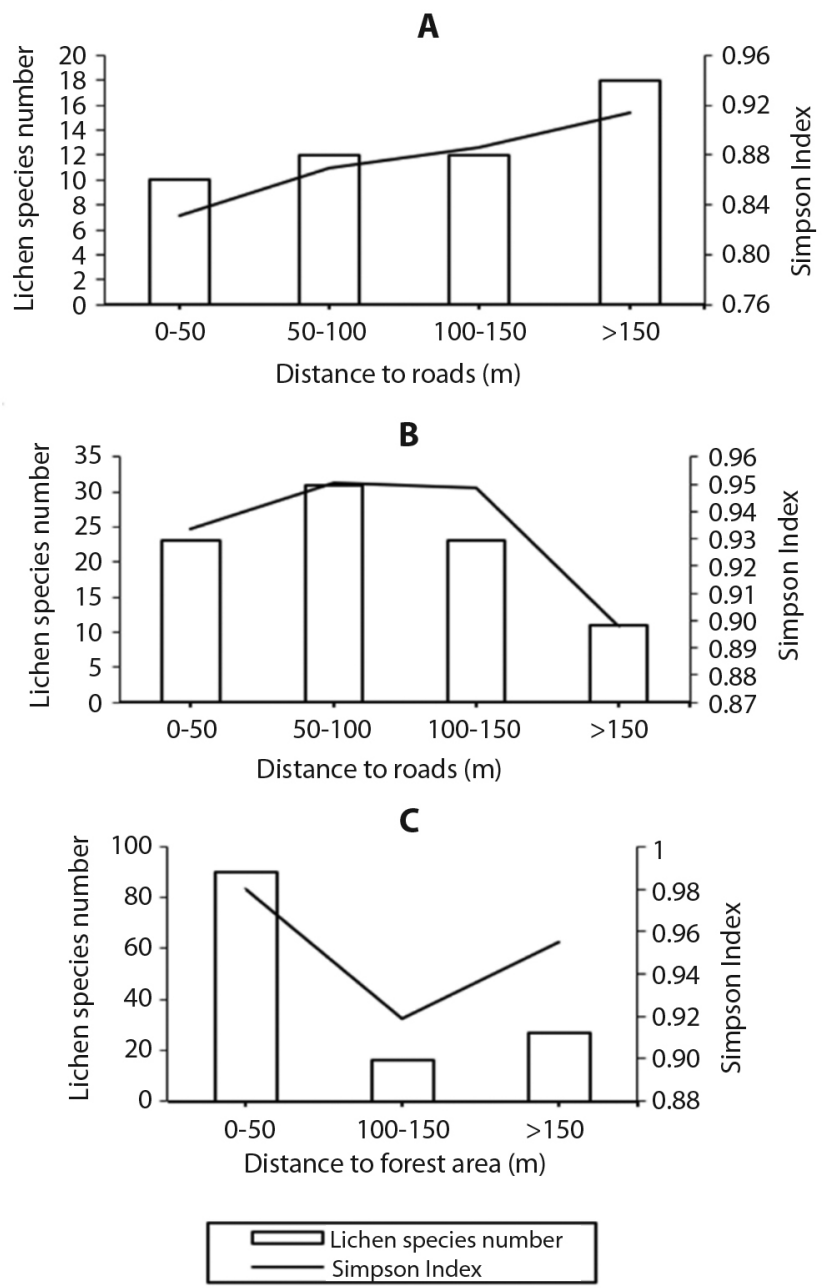

Fig. 8. Lichen species richness and Simpson Index in relation to distance to roads for A. Area 1 and B. Area 2 or C. In relation to distance at forest region for Area 3.

\section{DISCUSSION}

The results showed the presence of lichen species that indicate the state of intervention of the ecosystems. Species like $P$. chloantha has been documented in previous studies as a resistant specie, commonly found in strongly anthropogenically altered environments (Skirina \& Kozhenkova, 2018). On the other hand, Gupta et al. (2017) found that some species belonging to the genus Phaeophyscia are considered as indicator species in urban areas due to their ability to bioaccumulate heavy metals. Still, the $C$. concolor species has been informed as a tolerant species to contamination, as reported in studies such as Ochoa-Jiménez et al. (2015) and Saenz et al. (2007). Likewise, the species $C$. fibrosa was dominant in Area 3; this species was classified by Gonzales Vargas et al. (2016) as a species sensitive to contamination.

Areas with better air quality had more lichen richness and coverage, these findings coincide with previous studies that found relationships between lichen diversity and air 
A

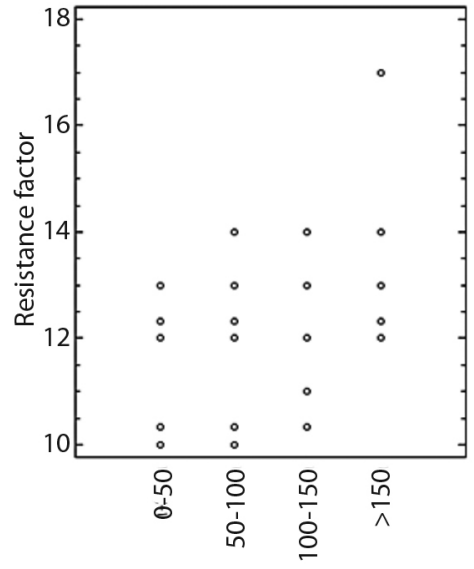

Distance to roads (m)
B

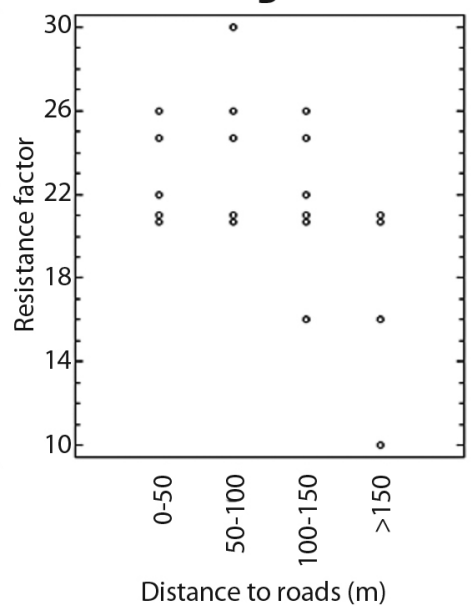

C

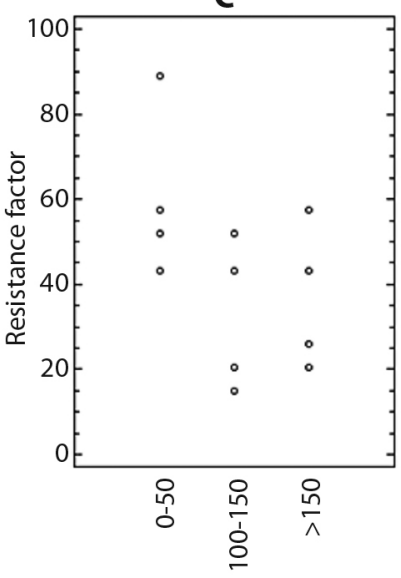

Distance to forest region $(\mathrm{m})$

Fig. 9. Q Factor in relation to the distance to roads A. Area 1 and B. Area 2 or in relation to distance to forest region $\mathbf{C}$. Area 3.

quality in different areas (Gombert et al., 2004; Käffer et al., 2011). Furthermore, the richness and abundance of lichens significantly respond to the concentrations of $\mathrm{PM}_{2.5}$ in a linear and negative way, so that the lichens in the study areas are clear indicators of the concentration of particles, and according to Varela et al. (2018), they can be used to estimate $\mathrm{PM}_{2.5}$ concentrations in areas that do not have monitoring stations.

At the zonal level, patterns of relationships were identified between observations of coverage and richness as well as the environmental and pollution characteristics of the zones. In Area 1, the contamination characteristics result in low richness and coverage values, and therefore, the establishment of lichens in the area depends on the tolerance of the species, their anatomy, their water retention capacity, and their mechanisms for detoxification of adverse effects, and according to experts, it may be modified by different environmental conditions and by the distribution area (Nimis et al., 1990).

Area 2 presents a homogeneous environment in terms of land use. Hence, variations and groups of coverage and richness could be associated with roads as their main source of pollution. For this zone, the richness increases as the sampled phorophytes are further from the surrounding pathways. This result is consistent with reports such as those presented by Perlmutter et al. (2017) and Will-Wolf et al. (2015). Note that there are responses related to changes in the composition of lichen communities. Moreover, the spatial heterogeneity of lichens in an area is greatly related to its land uses; thus, the air quality indexes established using lichens present higher values in garden areas and lower values in the vicinity of vehicular traffic. This coincides with the findings found by Ribeiro et al. (2016). Likewise, the Universidad Nacional de Medellin (located in Area 2) is characterized by having green corridors in its periphery, which makes the environment conducive to generating edge effects in microclimate conditions for the establishment of lichen communities (Aragón et al., 2015). Furthermore, these green corridors help reduce pollution levels (Hagler et al., 2011).

In area 3 , richness values presented greater responses for phorophytes that were within and near the forest zone. These relationships can be explained as the result of the adaptation of lichens to the pollution gradients that occur as the phorophytes sampled are located further 
away from the urban-rural zone and approach or locate in the forest zone. With respect to the latter, Barreno and Pérez-Ortega (2003) state that the proximity to forest mass structures is a key factor that should be considered, given that in or near forest areas, different types of microenvironments can be created that are immediately detected by the lichens and that can contribute to the creation of adequate conditions for the establishment of such communities. In addition, the presence of green areas increases humidity and is considered a barrier to air pollutants (Barreno \& PérezOrtega, 2003).

In general, lichen richness presented better relationships with respect to the environmental and pollution conditions of the different areas. This may be attributed to the fact that this indicator may present a greater sensitivity to the disturbances detected by lichens. In addition, the richness of lichens is considered a good element to determine for describing general environmental state characteristics of an area (Varela et al., 2018).

The obtained results indicate that the corticulous lichen communities present a response to environmental factors and pollution in biomonitoring areas. Moreover, it yields the knowledge of the quality of the environment with a high spatial resolution. This knowledge can be used as a warning to detect ecosystem damage and can provide crucial information regarding the generation of policies for land planning and ecosystem conservation. Therefore, these bioindicators can represent an environmental pillar toward sustainable development. Bioindication can answer crucial questions about risk without the need for an elaborate chemical analysis. Lichens can be used as warning systems for environmental problems, evaluation of the environmental health of an ecosystem, among others, since the lichen species disappearance may be more tangible than the "parts per trillion" of a chemical (Kienzl et al., 2003). Thus, establishing variations in the lichen communities between and within areas that allowed classifications and determining effects according to their exposure to contamination sources (routes) and land uses are possible; both are important responses for the study of air quality (Ulshöfer \& Rosner, 2001).

Relationships in composition of lichen communities associated to local pollution sources exposure and its extent limits were determined. This information may have great relevance in public health studies, since human beings located in these areas are exposed to the same complex mixture of pollutants to which lichens have been exposed to in this study. Based on the above, studies such as that of Cislaghi and Nimis (1997) highlight the importance of associating the monitoring of the diversity of lichens with the mortality rates. This finding represents a valuable tool for the knowledge of the environmental health in cities like Medellín that register areas with significant air quality alterations and that have a robust monitoring network for the diagnosis of air quality but do not have qualitative tools to assess its impact on living beings.

Ethical statement: authors declare that they all agree with this publication and made significant contributions; that there is no conflict of interest of any kind; and that we followed all pertinent ethical and legal procedures and requirements. All financial sources are fully and clearly stated in the acknowledgements section. A signed document has been filed in the journal archives.

\section{ACKNOWLEDGMENTS}

We thank to GIGA Research Group for financing this project.

\section{RESUMEN}

\section{Distribución espacial de las comunidades de líquenes y mapeo de la contaminación del aire en una ciudad tropical: Medellín, Colombia}

Introducción: Existe suficiente evidencia científica de los efectos nocivos de la contaminación atmosférica sobre la salud de los seres humanos, fauna, flora y ecosistemas en general. La primera opción para el diagnóstico de la calidad del aire son las redes de monitoreo mecánicas 
o electrónicas, pero estas no permiten evaluar de forma directa y precisa el impacto en los organismos vivos como resultado de la exposición a contaminantes del aire.

Objetivo: Evaluar los cambios en la composición de las comunidades de líquenes cortícolas como resultado a la exposición de factores de estrés ambiental en áreas con diferentes niveles de calidad del aire para diagnosticar el estado de contaminación o intervención en una zona de una manera más completa.

Métodos: Se determinaron los contrastes y cambios en la calidad del aire, la riqueza y cobertura de líquenes cortícolas en respuesta a diferentes factores de estrés, como usos del suelo y distancia a carreteras, en tres diferentes áreas de biomonitoreo, las cuales fueron evaluadas usando GIS. Los datos se presentan en un mapa de isolíneas con códigos en escala de grises fácil de entender.

Resultados: Indicadores como cobertura $(R=-0.4)$ y riqueza $(\mathrm{R}=-0.7)$ de líquenes están inversamente correlacionados con las concentraciones de $\mathrm{PM}_{2.5}$ en cada área. Se identificaron un total de 110 especies de líquenes, siendo Phaeophyscia chloantha (Ach.) Moberg y Physcia poncinsii Hue las especies más frecuentes (presentes en 38 y $33 \%$ de los 86 forófitos muestreados, respectivamente). Las relaciones intra-área de riqueza de líquenes exhiben relaciones significativas con respecto al uso del suelo y distancia a carreteras (con coeficientes de correlación mayores a 0.5) y el índice de Simpson fue mayor a 0.9, en lugares con mejores condiciones en términos de calidad del aire y microambientes. Asimismo, los factores de resistencia calculados sugieren que las especies más sensibles se pueden encontrar en ambientes con menor grado de perturbación.

Conclusión: Estas evaluaciones representan más elementos de criterio para el diagnóstico de la salud ambiental en las áreas de biomonitoreo.

Palabras clave: biomonitoreo; calidad del aire; líquenes cortícolas; factores de resistencia; mapeo de líquenes; diversidad de líquenes.

\section{REFERENCES}

Aguiar-Gil, D., Gómez-Peláez, L. M., Álvarez-Jaramillo, T., Correa-Ochoa, M. A., \& Saldarriaga-Molina, J. C. (2020). Evaluating the impact of PM2.5 atmospheric pollution on population mortality in an urbanized valley in the American tropics. Atmospheric Environment, 224, 117343. https://doi.org/10.1016/j. atmosenv.2020.117343

Alcaldía de Medellín. (2021). Geomedellín. Portal gráfico del municipio de Medellín. Web Page. https://www. medellin.gov.co/geomedellin/index.hyg

AMVA \& Clean Air Institute (2017). Plan integral de gestión de la calidad del aire para el área metropolitana del Valle de Aburrá 2017-2030. https://www.metropol.gov.co/ambiental/calidad-del-aire/Documents/ PIGECA/PIGECA-Aprobado-Dic-2017.pdf
Anze, R., Franken, M., Zaballa, M., Pinto, M. R., Zeballos, G., Cuadros, M. D. L. Á., Canseco, Á., Rocha, A. de, Estellano, V. H., \& del Granado, S. (2007). Bioindicadores en la detección de la contaminación atmosférica en Bolivia. Revista Virtual REDESMA, 53-74. https://cebem.org/revistaredesma/voll/pdf/ redesma0101_art03.pdf

Aragón, G., Abuja, L., Belinchón, R., \& Martínez, I. (2015). Edge type determines the intensity of forest edge effect on epiphytic communities. European Journal of Forest Res, 451, 443-451. https://doi. org/10.1007/s10342-015-0863-5

Augusto, S., Máguas, C., \& Branquinho, C. (2013). Guidelines for biomonitoring persistent organic pollutants (POPs), using lichens and aquatic mosses - A review. Environmental Pollution, 180, 330-338. https://doi. org/10.1016/j.envpol.2013.05.019

Barreno, E., \& Pérez-Ortega, S. (2003). Líquenes de la Reserva Natural Integral de Muniellos, Asturias. Principado de Asturias. Ediciones KRK. https://doi. org/10.15713/ins.mmj.3

BID (2016). Estudios de casos internacionales de ciudades inteligentes: Medellín, Colombia (Documento para discusión $\mathrm{N}^{\mathrm{o}}$ IDB-DP-443). Banco Interamericano de Desarrollo. https://publications.iadb.org/bitstream/ handle/11319/7716/Estudios-de-casos-internacionales-de-ciudades-inteligentes-Medellin-Colombia. pdf? sequence $=1$

Cakmak, S., Hebbern, C., Pinault, L., Lavigne, E., Vanos, J., Crouse, D. L., \& Tjepkema, M. (2018). Associations between long-term PM2.5 and ozone exposure and mortality in the Canadian Census Health and Environment Cohort (CANCHEC), by spatial synoptic classification zone. Environment International, 111, 200-211. https://doi.org/10.1016/j. envint.2017.11.030

Castro, M., Pinho, P., Llop, E., Branquinho, C., Soares, A., \& Joa, M. (2014). Associations between outdoor air quality and birth weight: a geostatistical sequential simulation approach in Coastal Alentejo,Portugal. Stochastic Environmental Research and Risk Assessment, 28, 527-540. https://doi.org/10.1007/ s00477-013-0770-6

Chai, T., \& Oceanic, N. (2015). Root mean square error (RMSE) or mean absolute error (MAE)? - Arguments against avoiding RMSE in the literature. Geoscientific Model Development, 7(3), 1247-1250. https://doi. org/10.5194/gmd-7-1247-2014

Chaparro, M., \& Aguirre, J. (2002). Hongos Liquenizados. Departamento de Biología, Facultad de Ciencias, Sede Bogotá, Universidad Nacional de Colombia.

Cislaghi, C., \& Nimis, P. L. (1997). Lichens, air pollution and lung cancer. Nature, 387(6632), 463-464. 
Green, J., \& Sánchez, S. (2012). La Calidad del Aire en América Latina: Una Visión Panorámica. In Clean Air Institute. https://www.minambiente.gov.co/ images/AsuntosambientalesySectorialyUrbana/pdf/ contaminacion_atmosferica/La_Calidad_del_Aire en_América_Lätina.pdf

Cleavitt, N. L., Hinds, J. W., Poirot, R. L., Geiser, L. H., Dibble, A. C., Leon, B., Perron, R., \& Pardo, L. H. (2015). Epiphytic macrolichen communities correspond to patterns of sulfur and nitrogen deposition in the northeastern United States. The Bryologist, 118(3), 304-324. https://doi. org/10.1639/0007-2745-118.3.304

Correa-Ochoa, M. A., Vélez-Monsalve, L. C., SaldarriagaMolina, J. C., \& Jaramillo-Ciro, M. M. (2020). Evaluation of the Index of Atmospheric Purity in an American tropical valley through the sampling of corticulous lichens in different phorophyte species. Ecological Indicators, 115, 106355. https://doi. org/10.1016/j.ecolind.2020.106355

Correa, M., Zuluaga, C., Palacio, C., Pérez, J., \& Jimenez, J. (2009). Surface wind coupling from free atmosphere winds to local winds in a tropical region within complex terrain. Case of study: Aburra Valley Antioquia, Colombia. Dyna, 76(158), 17-27.

Gaviria, C. F., Benavides, P. C., \& Tangarife, C. A. (2011). Contaminación por material particulado (PM2, 5 y PM10) y consultas por enfermedades respiratorias en Medellín (2008-2009). Revista Facultad Nacional de Salud Pública, 29(3), 241-250. https://www. minsalud.gov.co/sites/rid/Lists/BibliotecaDigital/ RIDE/INEC/IGUB/Diagnostico de salud Ambiental compilado.pdf

Gombert, S., Asta, J., \& Seaward, M. R. D. (2004). Assessment of lichen diversity by index of atmospheric purity (IAP), index of human impact (IHI) and other environmental factors in an urban area (Grenoble, southeast France). Science of the Total Environment, 324(1-3), 183-199. https://doi.org/10.1016/j. scitotenv.2003.10.036

Gonzales Vargas, N., Luján Pérez, M., Navarro Sánchez, G., \& Flores Mercado, R. (2016). Aplicabilidad de líquenes bioindicadores como herramienta de monitoreo de la calidad del aire en la ciudad de Cochabamba. Acta Nova, 7(4), 455-482.

Gupta, S., Rai, H., Kumar Upreti, D., Kumar Gupta, R., \& Kumar Sharma, P. (2017). Lichenized fungi Phaeophyscia (Physciaceae, ascomycota) as indicator of ambient air heavy metal deposition, along land use gradient in an alpine habitat of Western Himalaya. Pollution Research, 36(1), 150-157.

Hagler, G. S. W., Tang, W., Freeman, M. J., Heist, D. K., Perry, S. G., \& Vette, A. F. (2011). Model evaluation of roadside barrier impact on near-road air pollution. Atmospheric Environment, 45(15), 2522-2530. https://doi.org/10.1016/j.atmosenv.2011.02.030
Hawksworth, D. L., Iturriaga, T., \& Crespo, A. (2005) Líquenes como bioindicadores inmediatos de contaminación y cambios medio-ambientales en los trópicos. Revista Iberoamericana de Micología, 22(2), 71-82. https://doi.org/10.1016/S1130-1406(05)70013-9

IDEAM. (2018a). Atlas Climatológico de Colombia [Base de datos]. http://atlas.ideam.gov.co/visorAtlasClimatologico.html

IDEAM. (2018b). Información Aeronáutica Climatología. Régimen anual de viento: Medellín [Base de datos]. http://bart.ideam.gov.co/cliciu/rosas/viento.htm

INE. (2019). Manual 1. Principios de Medición de la calidad del aire. Instituto Nacional de Ecología Report. https://sinaica.inecc.gob.mx/archivo/guias/1-\%20 Principios\%20de\%20Medici\%C3\%B3n\%20de\%20 la $\% 20$ Calidad $\% 20$ del $\% 20$ Aire.pdf

James, G., Witten, D., Hastie, T., \& Tibshirani, R. (2013). An Introduction to Statistical Learning (Vol. 112, pp. 18). Springer. https://doi.org/10.1007/978-1-4614-7138-7

Jaramillo, M., \& Botero, L. (2010). Comunidades liquénicas como bioindicadores de calidad del aire. Revista Gestión y Ambiente, 13(1), 97-110.

Jovan, S. 2008. Lichen bioindication of biodiversity, air quality, and climate: baseline results from monitoring in Washington, Oregon, and California (Gen. Tech. Rep. PNW-GTR-737). U.S. Department of Agriculture, Forest Service, Pacific Northwest Research Station.

Käffer, M. I., Martins, S. M. D. A., Alves, C., Pereira, V. C., Fachel, J., \& Vargas, V. M. F. (2011). Corticolous lichens as environmental indicators in urban areas in southern Brazil. Ecological Indicators, 11(5), 13191332. https://doi.org/10.1016/j.ecolind.2011.02.006

Kienzl, K., Riss, A., Vogel, W., Hackl, J., \& Götz, B. (2003). Bioindicators and biomonitors for policy, legislation and administration. In Trace Metals and other Contaminants in the Environment (Vol. 6, pp. 85-122). Elsevier.

Li, T., Zhang, Y., Wang, J., Xu, D., Yin, Z., Chen, H., Lv, Y., Luo, J., Zeng, Y., Liu, Y., Kinney, P. L., \& Shi, X. (2018). All-cause mortality risk associated with longterm exposure to ambient PM2.5 in China: a cohort study. The Lancet Public Health, 3(10), e470-e477. https://doi.org/10.1016/S2468-2667(18)30144-0

Llop, E., Pinho, P., Matos, P., Pereira, M. J., \& Branquinho, C. (2012). The use of lichen functional groups as indicators of air quality in a Mediterranean urban environment. Ecological Indicators, 13(1), 215-221. https://doi.org/10.1016/j.ecolind.2011.06.005

MADS (2012). Diagnóstico Nacional de salud ambiental. Ministerio de Ambiente y Desarrollo Sostenible Report. https://www.minsalud.gov.co/sites/ rid/Lists/BibliotecaDigital/RIDE/INEC/IGUB/ 
Diagnostico\%20de\%20salud\%20Ambiental\%20 compilado.pdf

Monge-Nájera, J., González, M. I., Rivas Rossi, M., \& Méndez, V. H. (2002). A new method to assess air pollution using lichens as bioindicators. Revista de Biología Tropical, 50(1), 321-325. http://www.ncbi. nlm.nih.gov/pubmed/12298260

Nimis, P. L., Castello, M., \& Perotti, M. (1990). Lichens as biomonitors of sulphur dioxide pollution in la spezia (northern Italy). The Lichenologist, 22(3), 333-344. https://doi.org/10.1017/S0024282990000378

Ochoa-Jiménez, D. A., Prieto, M., Aragón, G., \& Benitez, Á. (2015). Cambios en la composición de líquenes epífitos relacionados con la calidad del aire en la Ciudad de Loja (Ecuador). Caldasia, 2(37), 333-343. https://doi.org/10.15446/caldasia.v37n2.53867

Orange, A., James, P. W., \& White, F. J. (2001). Microchemical methods for the identification of lichens. British Lichen Society.

Perlmutter, G. B., Blank, G. B., Wentworth, T. R., Lowman, M. D., Neufeld, H. S., \& Plata, E. R. (2017). Effects of highway pollution on forest lichen community structure in western Wake County, North Carolina, U.S.A. The Bryologist, 120(1), 1-10. https://doi. org/10.1639/0007-2745-120.1.001

Piercey-Normore, M. D., \& DePriest, P. T. (2001). Algal switching among lichen symbioses. American Journal of Botany, 88(8), 1490-1498. https://doi. org $/ 10.2307 / 3558457$

Pollard, A. S., Williamson, B. J., Taylor, M., Purvis, W. O., Goossens, M., Reis, S., Aminov, P., Udachin, V., \& Osborne, N. J. (2015). Integrating dispersion modelling and lichen sampling to assess harmful heavy metal pollution around the Karabash copper smelter, Russian Federation. Atmospheric Pollution Research, 6(6), 939-945. https://doi.org/10.1016/j. apr.2015.04.003

Ribeiro, M. C., Pinho, P., Branquinho, C., Llop, E., \& Pereira, M. J. (2016). Science of the Total Environment Geostatistical uncertainty of assessing air quality using high-spatial-resolution lichen data: A health study in the urban area of Sines, Portugal. Science of the Total Environment, 562, 740-750. https://doi. org/10.1016/j.scitotenv.2016.04.081

RStudio Team (2020). RStudio: Integrated Development for R. RStudio. https://rstudio.com

Saenz, A. E., Flores, F., Madrigal, L., \& Di Stefano, J. F. (2007). Estimación del grado de contaminación del aire por medio de la cobertura de líquenes sobre troncos de arboles en la ciudad de San José, Costa Rica. Brenesia, 68(68), 29-35.
Salcedo, S., Vargas Rojas, D. L., \& Morales Puentes, M. E. (2014). Use of Non Vascular Plant Organisms as Indicators of Urban Air Pollution (Tunja, Boyacá, Colombiano). Acta Biológica Colombiana, 19(2), 221. https://doi.org/10.15446/abc.v19n2.40681

SIATA. (2020). Sistema de Alertas Tempranas de Medellin y el Valle de Aburrá - SIATA. https://siata.gov.co/ siata nuevo

Simpson, E. (1949). Measurement of species diversity. Nature, 163(4148), 688-688.

Skirina, I. F., \& Kozhenkova, S. I. (2018). ЛИХЕНОИНДИКАЦИЯ ЗАГРЯЗНЕНИЯ ПРИЗЕМНОГО ВОЗДУХА ГОРОДА НАХОДКА (ПРИМОРСКИЙ КРАЙ). Botanicheskii Zhurnal, 90(8), 1184-1196.

Szpiro, A. A., Sheppard, L., Sampson, P. D., \& Kim, S. Y. (2007). Validating National Kriging Exposure Estimation. Environmental Health Perspectives, 115(7), 338-344. https://doi.org/10.1289/ehp.10205

Ulshöfer, J., \& Rosner, H. J. (2001). GIS-based analysis of lichen mappings and air pollution in the area of Reutlingen (Baden-Württemberg, Germany). Meteorologische Zeitschrift, 10(4), 261-265. https://doi. org/10.1127/0941-2948/2001/0010-0261

Van Dijk, C., Van Doorn, W., \& Van Alfen, B. (2015). Chemosphere Long term plant biomonitoring in the vicinity of waste incinerators in The Netherlands. Chemosphere, 122, 45-51. https://doi.org/10.1016/j. chemosphere.2014.11.002

Varela, Z., López-Sánchez, G., Yáñez, M., Pérez, C., Fernández, J. A., Matos, P., Branquinho, C., \& Aboal, J. R. (2018). Changes in epiphytic lichen diversity are associated with air particulate matter levels: The case study of urban areas in Chile. Ecological Indicators, 91, 307-314. https://doi.org/10.1016/j. ecolind.2018.04.023

WHO (2006). Guías de calidad del aire de la OMS relativas al material particulado, el ozono, el dióxido de nitrógeno y el dióxido de azufre. Actualización mundial 2005. World Health Organization Report. https:// apps.who.int/iris/bitstream/handle/10665/69478/ WHO SDE PHE OEH 06.02 spa.pdf;jsessionid= 79827B3E74CD9331BA 68 DAF66A9B2C3CD?sequ ence $=1$

WHO (2016a). Ambient Air Pollution: A global assessment of exposure and burden of disease. World Health Organization Report. http://apps.who.int/iris/bitstream/handle/10665/250141/9789241511353-eng. pdf? sequence $=1$

WHO (2016b). La OMS publica estimaciones nacionales sobre la exposición a la contaminación del aire y sus 
repercusiones para la salud. World Health Organization Webpage. https://www.who.int/es/news-room/ detail/27-09-2016-who-releases-country-estimateson-air-pollution-exposure-and-health-impact

Will-Wolf, S., Makholm, M. M., Nelsen, M. P., Trest, M. T., Reis, A. H., \& Jovan, S. (2015). Element analysis of two common macrolichens supports bioindication of air pollution and lichen response in rural midwestern U.S.A. The Bryologist, 118(4), 371-384. https:// doi.org/10.1639/0007-2745-118.4.371
Willmott, C. J., Robeson, S. M., \& Matsuura, K. (2012). A refined index of model performance. International Journal of Climatology, 32, 2088-2094. https://doi. org/10.1002/joc.2419

Yatawara, M., \& Dayananda, N. (2019). Use of corticolous lichens for the assessment of ambient air quality along rural - urban ecosystems of tropics : a study in Sri Lanka. Environmental Monitoring Assessment, 191-179. https://doi.org/https://doi.org/10.1007/ s10661-019-7334-2 